\title{
Influence of maturity stage of mango at harvest on its ripening quality
}

\author{
Emmanuel DICK ${ }^{1 *}$, Achille N'DA ADOPO ${ }^{2}$, Brahima CAMARA $^{1}$, Emmanuel MOUDIOH ${ }^{1}$
}

${ }^{1}$ Lab. Plant Physiol., Univ. Cocody-Abidjan, UFR Biosciences, 22 BP 582, Abidjan 22, Côte d'Ivoire dickoulaka@yahoo.fr

${ }^{2}$ Natl. Agron. Res. Cent. (CNRA), 01 Bp 1740, Abidjan 01, Côte d'Ivoire
${ }^{*}$ Correspondence and reprints

Fruits, 2009, vol. 64, p. 13-18 (C) 2009 Cirad/EDP Sciences All rights reserved DOI: $10.1051 /$ fruits:2008045 www.fruits-journal.org

RESUMEN ESPAÑOL, p. 18

\section{Influence of maturity stage of mango at harvest on its ripening quality.}

Abstract - Introduction. The subjectivity of the external criteria used for the determination of mango maturity at its harvest led to the search for additional more reliable parameters to determine the optimal harvest maturity and able to replace the external and internal morphological indices. Materials and methods. Some physicochemical characteristics, such as colour of pulp, soluble dry extract, titratable acidity and weight loss, were evaluated on fruits of the cv. Kent (Mangifera indica L.) collected in North Cote d'Ivoire. The days necessary for ripening after harvest were estimated. Measurements were correlated to five maturity stages corresponding to the fruit harvest carried out at $(76,82,88,94$ and 100) days after flowering. On each date of harvest, batches of 52 fruits were gathered. On half of them, maturation was observed as of harvest, the other half being kept at room temperature and the ripening evaluation then being done at the end of storage. Results. According to the harvest date, the soluble dry extract values varied from $8.3^{\circ} \mathrm{Brix}$ to $10^{\circ} \mathrm{Brix}$ at fruit harvest, and from $14.2^{\circ} \mathrm{Brix}$ to $20^{\circ} \mathrm{Brix}$ after ripening of the fruits stored at ambient temperature. Titratable acidity was correlated positively with maturity stage. Time to ripen and weight loss continuously decreased with the fruit maturity. For mangos of the $\mathrm{cv}$. Kent, the date of the most suitable harvest seemed to be at 94 days after flowering. Mangos collected at 100 days after flowering developed better organoleptic characteristics such as sugar content, peel aspect and pulp colour than those of the fruit harvested earlier. Conclusion. Starting from the 94th day after flowering, the mango of the cv. Kent collected under the conditions of the North Cote d'Ivoire develops its best organoleptic characteristics during ripening.

Cote d'Ivoire / Mangifera indica / fruits / harvesting / maturation / ripening

\section{Influence du stade de maturité de la mangue à la récolte sur son mûris-} sement.

Résumé - Introduction. La subjectivité des critères externes utilisés pour la détermination de la maturité de la mangue à sa récolte a conduit à rechercher d'autres paramètres plus fiables pour déterminer la maturité optimale de récolte et aptes à remplacer les index morphologiques externes et internes. Matériel et méthodes. Certaines caractéristiques physico-chimiques, tels que la couleur de la pulpe, l'extrait sec soluble, l'acidité titrable et la perte de poids, ont été évaluées sur des fruits du cv. Kent (Mangifera indica L.) récoltés en Nord Côte-d'Ivoire. Les jours nécessaires au mûrissement ont été estimés. Les mesures ont été corrélées à cinq étapes de maturité correspondant à la récolte des fruits effectuée à $(76,82,88,94$ et 100) jours après floraison. À chaque date de récolte, des lots de 52 fruits ont été cueillis. Sur la moitié d'entre eux, la maturation a été observée dès la récolte, l'autre moitié étant conservée à la température ambiante et l'évaluation du mûrissement se faisant alors en fin de stockage. Résultats. Selon la date de récolte, les valeurs de l'extrait sec soluble ont varié de $8.3^{\circ}$ Brix à $10^{\circ}$ Brix lors de la récolte, et de $14.2^{\circ}$ Brix à $20^{\circ}$ Brix après mûrissement des fruits stockés à température ambiante. L'acidité titrable a été corrélée positivement avec le stade de maturité. Le délai de mûrissement et la perte de poids ont continuellement diminué avec la maturité des fruits. Pour des mangues du cv. Kent, la date de récolte la plus appropriée a semblé être à 94 jours après floraison. La mangue récoltée à 100 jours après floraison a développé des caractéristiques organoleptiques telles qu'une teneur en sucre, un aspect de peau et une couleur de pulpe différentes de celles du fruit récolté plus tôt. Conclusion. À partir du quatre-vingt-quatorzième jour après floraison, la mangue du cv. Kent récoltée dans les conditions du nord de la Côte d'Ivoire développe au mieux ses caractéristiques organoleptiques au cours du mûrissement.

Côte d'Ivoire / Mangifera indica / fruits / récolte / maturation / mûrissage 


\section{Introduction}

In general, the external morphological criteria such as fruit size, colour of peel and fruit shape help to estimate the stage of maturity for harvesting mango fruit [1] Other elements such as the internal pulp colour are used to attest fruit maturation with the global external morphology [2]. The ripening process at ambient temperature depends on the cultivar and stage of fruit maturity at harvest [3]. The subjectivity aspect of external criteria for determination of harvest maturity has led to the search for additional parameters that are able to reflect a more reliable criterion on the basis of which the harvested mango fruit should develop optimal organoleptic traits after ripening. Therefore, colour of the pulp, sugar levels evaluated by soluble dry extract, titratable acidity and external appearance of mango fruit were assessed in relation to the maturity stage.

\section{Materials and methods}

Experiments were done with mango (Mangifera indica $\mathrm{L}$. cv. Kent) fruit sourced from plots of Lataha research station, in the northern country, around Korhogo, the principal town in this region of Côte d'Ivoire. This variety is the one in most demand among those intended for export because of its attractive colour during ripening, and mainly for its less stringy pulp.

The maturity stage of mango fruits was assessed by identifying the date of the opening of the final flower of panicles and by following marked inflorescences. Fruits were harvested at $(76,82,88,94$ and 100) days following these labelled dates of blooming. A batch of 52 fruits was collected at each harvest date. Ripening was observed on half of each batch stored at ambient temperature $\left[(28 \pm 2){ }^{\circ} \mathrm{C}\right]$ for $(8$ to 18$) \mathrm{d}$ according to the maturity stage at harvest until fruits reached full yellowing of peel. Measurements were also made on the other half at the harvest time.

Physicochemical characteristics were assessed on green fruits after harvest and on full yellow ones after ripening as follows:
- the level of soluble dry extract (SDE), indicating the rate of soluble sugar of the pulp, was estimated in ${ }^{\circ}$ Brix with a Pr-1 Atago type refractometer,

- titratable acidity was measured with sodium hydroxide solution $0,1 \mathrm{~N}$ in the presence of phenolphthalein in $10 \mathrm{~mL}$ of solution obtained from $1 \mathrm{~g}$ of pulp homogenised with $25 \mathrm{~mL}$ distilled water and filtered. Results are expressed as $\mathrm{mEq} \cdot 10 \mathrm{~g}^{-1}$ of fresh pulp,

- time to ripen, as the length in days of ripening, was characterised by full yellowing and softening of the fruits,

- medium colour of the pulp (in arbitrary units) assessed with a colorimetric scale ranging from 2 to 18 [4], as the average index between data around the stone and near the peel,

- shrivelling or smooth aspect of the peel during storage was appreciated by a single observation,

- weight loss of fruits was measured with a scale of average precision of Sartorius type.

Statistical analysis of data was carried out using SPSS software. It was related to the analysis of the variance by the General Linear Model (GLM) procedure. This method makes it possible to check if the differences between the averages of measurements are significant. It ensures the comparison of variability between various batches and inside a considered batch. Duncan's test was also used.

\section{Results}

\subsection{Soluble dry extract and titratable acidity}

Generally, the mango fruit soluble dry extract (SDE), or soluble sugar, was higher after ripening than at harvest (figure 1). Levels of SDE increased very slightly at harvest from the 76th to the 88th days after blooming and showed a relative increase from the 94th day. The collected values varied from (8.3 to 10$)^{\circ}$ Brix. During ripening, SDE piled 
up more or less quickly depending on the maturity stage of mango fruits, leading to higher concentrations of this component; it varied from $14.2^{\circ}$ Brix at the 76 th day after blooming to $20^{\circ}$ Brix at the 100th day (figure 1). After ripening, the values were almost double those obtained at the time of harvest. The more the harvest time of fruits was delayed, the more the soluble dry extract increased, both with green fruits after harvest and with full yellow ones after ripening.

For fruits observed at harvest, titratable acidity increased significantly until the 88th day; it was constant between the 88th and the 94th days; then, it decreased significantly at the 100th day (figure 1). The corresponding values varied from (10.4 to 12.5) $\mathrm{mEq} \cdot 10 \mathrm{~g}^{-1}$ of fresh pulp, then decreased to $11.3 \mathrm{mEq} \cdot 10 \mathrm{~g}^{-1}$. On the other hand, for fruits observed at the end of ripening, acidity increased regularly and slowly from $5.1 \mathrm{mEq} \cdot 10 \mathrm{~g}^{-1}$ at the 76 th day to $6.8 \mathrm{mEq} \cdot 10 \mathrm{~g}^{-1}$ at the 94 th day, then it accelerated subsequently from this stage to reach $9.0 \mathrm{mEq} \cdot 10 \mathrm{~g}^{-1}$ at the 100th day. The acidity of fruits dropped with ripening. For fruits observed after ripening, the more mature they were, the higher their acidity.

\subsection{Ripening time and colour of the pulp}

The ripening time decreased continuously with the fruit maturity and presented three steps (figure 2): firstly, a very pronounced stage between the 76th and the 88th days after blooming with, respectively, (18 and 12) days to reach full yellowing of peel, then a relatively stable period between the stages of the 88th and the 94th days, and, lastly, a new but less pronounced step from the 94th to the 100th days during which ripening time fell from (12 to 10) days.

The colour index of the pulp observed at harvest increased regularly, with fruits maturing especially from the 88th day and reaching the index 12 at the 100th day (figure 2). During storage for ripening, no relative variation was observed from the 76th to the 88th days after blooming. This first step was followed by a general increase

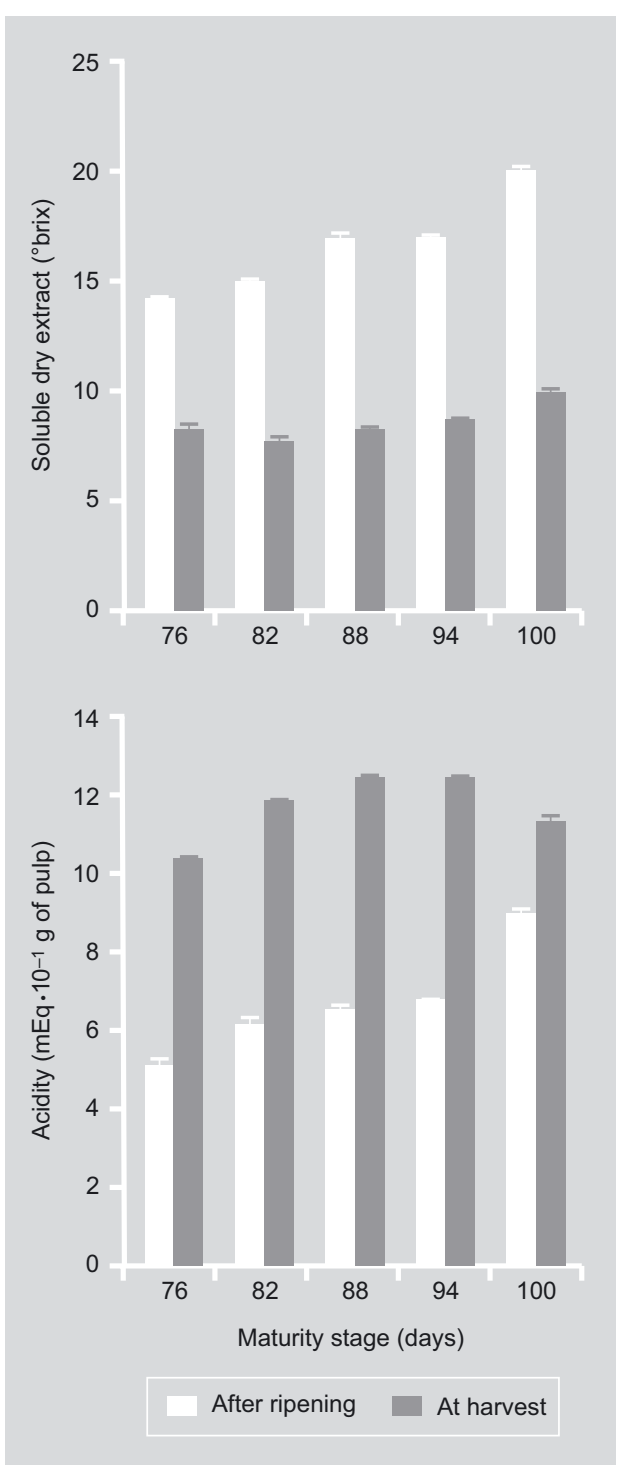

Figure 1.

Evolution of soluble dry extract and titratable acidity of mango fruit pulp according to the fruit harvest date (number of days after blooming). Comparison between fruits observed at the harvest time and fruits observed after ripening at ambient temperature. The superscript bars with different letters are statistically different according to Duncan's test. in colour after the 88th day leading to the index 18 at the 100th day (figure 2).

\subsection{Weight loss and peel aspect}

Weight loss decreased constantly during storage (figure 3). Final values recorded were $20.9 \%$ for the 76 th day and $13.4 \%$ for the 100th day after blooming. The rate of shrivelled fruits during storage for ripening was higher with the fruits harvested more precociously (figure 3). Fruits harvested from the 76 th to the 82 nd day resulted in 
Figure 2.

Ripening time and colour index (arbitrary index) of mango fruit pulp according to the fruit harvest date (number of days after blooming). Comparison between fruits observed at the harvest time and fruits observed after ripening at ambient temperature. The superscript bars with different letters are statistically different according to Duncan's test.

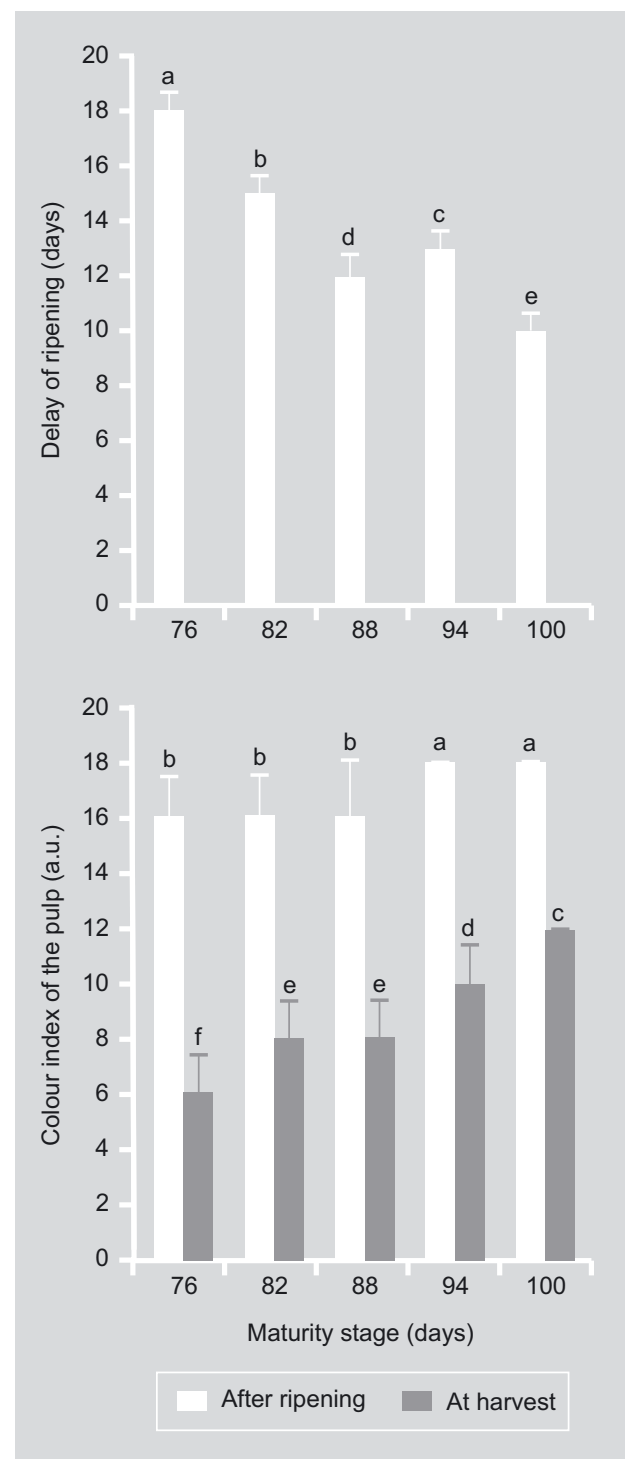

$100 \%$ of shrivelled peel. The level of fading decreased slowly from the 88th to the 94th day and then it accelerated. A value of 37\% was recorded for the fruits harvested at the 100th day after blooming.

\section{Discussion}

Our experiment aimed at objectively characterising optimum harvest maturity for mango (M. indica L. Cv. Kent) fruits, the limit of maturity for harvest such that the fruit fully ripen. A weak variation in soluble dry extract (about $2{ }^{\circ}$ Brix) was observed in fruit at harvest from the 76 th to the 100th days after blooming, against $6{ }^{\circ}$ Brix recorded after ripening. This result indicates that there is a small production of soluble sugars from starch stored in green mango during development on the tree. The later the harvest maturity, the higher the level of staple sugar in the fruit. It therefore seems that ripening starts slowly and incompletely when fruits are still tied to the plant.

As the level of sugars increases weakly on the tree, so the rate of titratable acidity slowly reaches the maximum value, then decreases. These results are similar to those found by Lebrun et al. [5].

Concomitant increase in sugar and acidity during ripening supports the fact that the taste of fruits depends on the sugar-acid balance [6].

The ripening time greatly depends on the maturity stage of fruits at the harvest. Fruits harvested at a less mature stage stay green for a long time before ripening, totally unlike those harvested later. This fact is apparently typical of climacteric fruits, and has been observed on some other cultivars of mango such as Tommy Atkins [7] as well as papaya [8]. It has been used depending on the trade objective [9]. Thus, more or less matured fruits, respectively, are collected for local or export markets.

For fruits harvested from the 76th to the 88th days after blooming, pulp colour is light yellow at the end of ripening; it is orange from the 94th to the 100th days after flowering. This is probably an indication that physiological maturity of Kent mango fruit is reached at the 94th day after flowering.

In other respects, the weight loss by the time of total ripening with less mature mango fruits could be the logical effect of a long time in storage due to delayed ripening and physiological immaturity. Generally, less mature fruits are less filled with reserve substances and are much more susceptible to a higher rate of transpiration and water loss during storage. 


\section{Conclusion}

Extending harvest of mangos in order to collect fruits of different maturity stages helped to characterise the fruit and to analyse their aptitude in regards to ripening. Ninety-four days after the opening date of the panicle final flower seems to be the beginning of physiological change in maturity of Kent mango fruit in our study. From this maturity stage, the fruit develops its best organoleptic traits during ripening. Although we did not extend the experiment to a maturity stage beyond 100 days, it can be stated that 94 days and later could stand for the time of physiological maturity. Thus, this time appears as the most suitable date of harvest to have, in a short ripening time, sweet and fairly acid Kent mango fruits, with an orange-coloured pulp and a less shrivelled peel.

\section{References}

[1] Iznaga F.A., Harvesting and marketing, Escoagroservice Bull. 15 (1978) 23-28.

[2] Subedi P.P., Walsh K.B., Owens G.P., Prediction of mango eating quality at harvest using short-wave near infrared spectrometry, Postharvest Biol. Technol. 43 (2007) 326334.

[3] Lalel H.J.D., Singh Z., Tan S.C., Aroma volatiles production during fruit ripening of Kensington Pride mango, Postharvest Biol. Technol. 27 (2003) 323-336.

[4] Anon., La qualité de la banane, la réglementation française et son interprétation, IRFA / Minist. Agric., Paris, France, 1980, 74 p.

[5] Lebrun M., Plotto A., Goodner K., Ducamp M.N., Baldwin E.A., Discrimination of mango fruit maturity by volatiles using the electronic nose and gas chromatography, Postharvest Biol. Technol. 48 (2008) 122-131.

[6] Laroussilhe F., Le manguier, Tech. Agric. Prod. Trop., Maisonneuve et Larose, Paris, France, 1980, $312 \mathrm{p}$.

[7] Baldwin E., Burns J.K., Kazokas W., Brecht J.K., Hagenmaier R.D., Bender R.J., Pesis E., Effect of two edible coatings with different permeability characteristics on mango

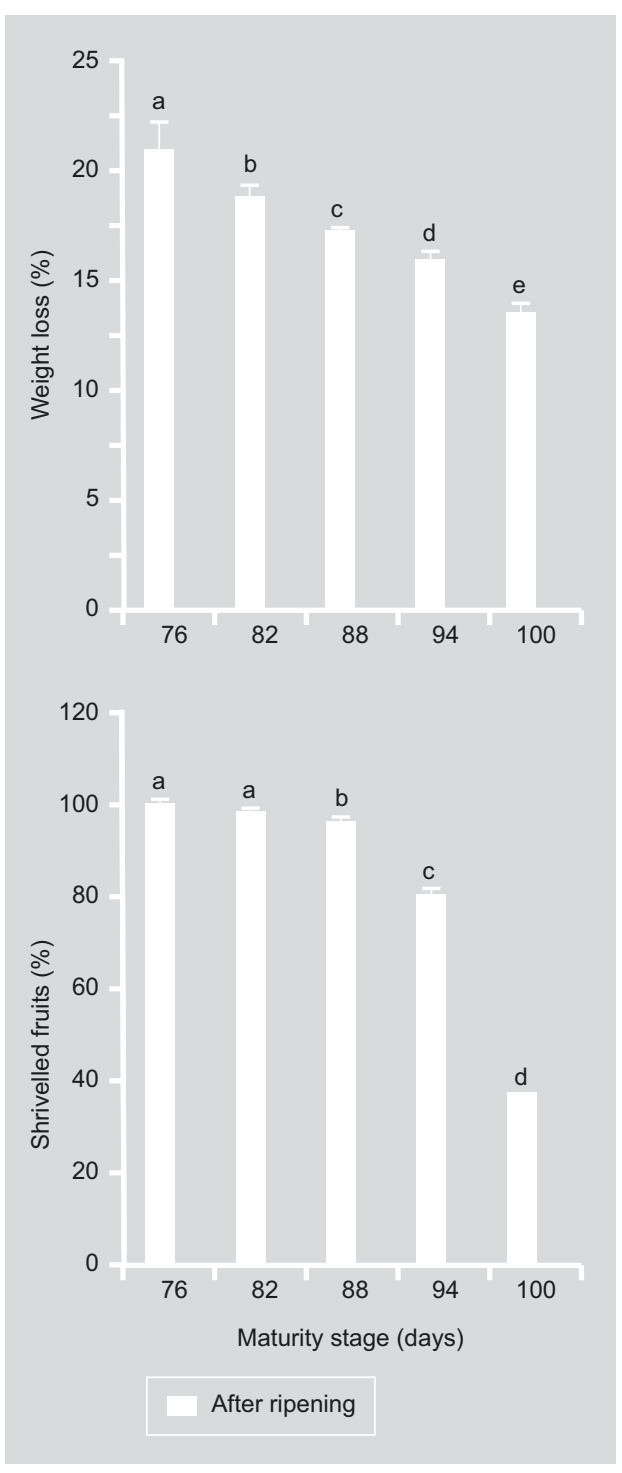

Figure 3.

Level of weight loss and shrivelled mango fruits after ripening according to the fruit harvest date (number of days after blooming).

The superscript bars with different letters are statistically different according to

Duncan's test.
(Mangifera indica L.) ripening during storage, Postharvest Biol. Technol. 17 (1999) 215226.

[8] Paull R.E., Nishijima W., Reyes M., Cavaletto C., Postharvest handling and losses during marketing of papaya (Carica papaya L.), Postharvest Biol. Technol. 11 (1997) 165179.

[9] N'Da Adopo A., Lassoudière A., Tchango Tchango J., Importance du stade de récolte pour la commercialisation de la banane plantain au Cameroun, Fruits 51 (1996) 397406. 


\section{Influencia del estado de madurez del mango en la cosecha sobre su maduración.}

Resumen - Introducción. La subjetividad de los criterios externos empleados para la determinación de la madurez del mango en su cosecha llevó a investigar otros parámetros más fiables para determinar la madurez óptima de cosecha y que fueran aptos a sustituir los índices morfológicos externos e internos. Material y métodos. Se evaluaron ciertas características físico-químicas, como el color de la pulpa, el extracto seco soluble, la acidez triturable y la pérdida de peso, en frutos del cv. Kent (Mangifera indica L.) cosechados en el norte de Côte-d'Ivoire. Se estimaron los días necesarios para la maduración. Se correlacionaron las medidas en cinco etapas de madurez que correspondía con la cosecha de los frutos efectuada a los $(76,82,88,94$ y 100) días tras la floración. En cada fecha de cosecha se cogieron lotes de 52 frutos. Se observó la maduración en la mitad de éstos en el momento de la cosecha; la otra mitad se conservó a temperatura ambiente, por lo que la evaluación de la maduración se hizo al final del almacenamiento. Resultados. Conforme con la fecha de cosecha, variaron los valores del extracto seco soluble de $8.3^{\circ}$ Brix a $10^{\circ}$ Brix en el momento de la cosecha, y de $4.2^{\circ}$ Brix a $20^{\circ}$ Brix tras maduración de los frutos almacenados a temperatura ambiente. La acidez triturable se relacionó positivamente con el estado de madurez. El plazo de maduración así como la pérdida de peso disminuyeron continuamente con la madurez de los frutos. Para los mangos del cv. Kent, la fecha de cosecha más apropiada pareció ser a los 94 días después de su floración. El mango cosechado tras 100 días después de la floración desarrolló características organolépticas tales como un contenido en azúcar, un aspecto de piel y un color de pulpa diferentes a aquellos del fruto cosechado con anterioridad. Conclusión. Tras el nonagésimo cuarto día después de floración, el mango del cv. Kent cosechado en las condiciones del norte de Côte-d'Ivoire desarrolla del mejor modo sus características organolépticas en el trascurso de la maduración.

Cote d'Ivoire / Mangifera indica / frutas / cosecha / maduración / maduramiento 